\title{
Physico-chemical characteristics of olive leaves and fruits and their relation with Bactrocera oleae (Rossi) cultivar oviposition preference
}

\author{
Ricardo Malheiro $^{\mathrm{a}, \mathrm{b}}$, Susana Casal ${ }^{\mathrm{b}}$, Paula Baptista ${ }^{\mathrm{a}}$, José Alberto Pereira ${ }^{\mathrm{a}, *}$ \\ a Mountain Research Centre (CIMO), School of Agriculture, Polytechnic Institute of Bragança, Campus de Santa Apolónia, Apartado 1172, $5301-855$ \\ Bragança, Portugal \\ ${ }^{\mathrm{b}}$ LAQV/REQUIMTE/Laboratory of Bromatology and Hydrology, Faculty of Pharmacy, Porto University, Rua de Jorge Viterbo Ferreira, 228, 4050 -313 Porto, \\ Portugal
}

\section{A R T I C L E I N F O}

\section{Article history:}

Received 30 May 2015

Received in revised form 7 August 2015

Accepted 11 August 2015

Available online 27 August 2015

\section{Keywords:}

Olives

Olive color

Physical parameters

Olive fly

Oviposition preference

\begin{abstract}
A B S T R A C T
Bactrocera oleae (Rossi) (Diptera: Tephritidae) oviposition preference to Portuguese olive cultivars with different susceptibilities (cvs. Cobrançosa, Madural, and Verdeal Transmontana) was studied by physical and chemical parameters. Physical parameters, maturation indices, infestation levels, and fatty acids profiles were recorded.

Verdeal Transmontana olives revealed higher susceptibility to olive fly attack, while cv. Cobrançosa was the less affected cultivar. A faster maturation in cv. Cobrançosa and a slower one in cv. Verdeal Transmontana were observed. Verdeal Transmontana olives reported higher volume and lower elongation, while both olives and leaves reported higher lightness, all possible attractive cues for olive fly. Fatty acids composition revealed a characteristic profile in each cultivar with constant differences during crop season.

Overall, maturation process influenced biometrical data and color of olive cultivars. The slower maturation process characteristic from cv. Verdeal Transmontana could modulate the composition and physical appearance of olives, therefore interfering with olive fly females oviposition preference.
\end{abstract}

(c) 2015 Elsevier B.V. All rights reserved.

\section{Introduction}

Olives production is steadily increasing in the last years worldwide, with about 20.3 million tons in 2013, the second highest production level ever accomplished (FAOSTAT, 2015). Since ancient times, the olive fly, Bactrocera oleae (Rossi) (Diptera: Tephritidae), has been one of the key pests of olive crops (Daane and Jonhson, 2010) and a simultaneous increase and widespread attacks are being reported. Indeed, a significant drop in olives production is expected in the 2014/2015 campaign, mainly attributed to olive fly attack. In the case of olive oil, a $27 \%$ reduction comparatively to the $2013 / 2014$ campaign is expected (IOC, 2014). This will lead to a general increase of olive oil prices for consumers in 2014/2015, as well as a certain reduction in quality due to olive fly attack. Olive females lay their eggs on olives and once hatched, the larvae feeds on olive pulp. The galleries created inside the olive and the exit holes opened to allow pupae and/or adult to exit cause severe quality drop in olive oils (Gómez-Caravaca et al., 2008; Pereira et al., 2004). Therefore,

\footnotetext{
* Corresponding author. Tel.: +351 273303277; fax: +351 273325405

E-mail address: jpereira@ipb.pt (J.A. Pereira).
}

the impact of this pest in olive crop is substantial, has been increasing in the recent years, requiring efficient strategies to prevent these losses.

Interestingly, olive fly attack does not affect all olive cultivars similarly. Certain olive cultivars present systematically lower levels of infestation comparatively to others cultivars inserted in the same agro-climatic niche. Therefore, the study of the olive fly-olive tree interaction may give us important information on how or which are the aspects that may influence the olive fly oviposition preference. The main aspects studied so far respect to chemical, physical and molecular aspects. In respect to physical factors parameters related to the hardness and elasticity of olives epidermis (Gonçalves et al., 2012), volume (Rizzo et al., 2012), and color (Katsoyannos et al., 1985) reported to be important in the oviposition preference of olive fly. Gonçalves et al. (2012) verified that olive fly prefer olives with harder pulp, corresponding to lower elasticity, which facilitate ovipositor penetration in the drupe. By other hand higher volumes olives are also highly preferred by olive fly, with higher odds of infestation being attributed to these olives (Rizzo et al., 2012). Another important factor is the olive color, intrinsically related with maturation, with greener and yellow colors attracting more olive flies than reddish and black colors ones (Katsoyannos et al., 1985). 
Once physical factors could give us information on the oviposition preference of olive fly, in the present work we intend to study the influence of physical parameters of both olives and olive leaves in the oviposition preference of olive fly in three Portuguese olive cultivars with different susceptibility degrees towards this pest: Cobrançosa (less susceptible), Madural (intermediate susceptibility), and Verdeal Transmontana (high susceptibility). To achieve such goal, biometric data was taken from olives (weight, maximum and minimum diameters, length, volume, and elongation) and olive leaves (length, width, and weight), as well as their color during crop season evolution. Simultaneously, infestation levels and maturation indices were also monitored in the three olive cultivars while the fatty acids profile was included to verify their possible action in the attraction of olive fly females.

\section{Material and methods}

In the present study, all biological material used was collected from an organic olive grove located in Paradela (Mirandela-41 ${ }^{\circ} 32^{\prime} 35.72^{\prime \prime} \mathrm{N} ; \quad 7^{\circ} 07^{\prime} 27.17^{\prime \prime} \mathrm{W}$ ) Trás-os-Montes region (Northeast of Portugal) in 2013. The study focused on three of the main cultivars of this region, Cobrançosa, Madural and Verdeal Transmontana. From each olive cultivar, five trees were selected and marked in order to collect all biological material needed for the necessary parameters, as detailed below.

\subsection{Infestation level and maturation index determination}

In previously selected and marked olive trees the infestation level and maturation index were determined. Both parameters were assessed fortnightly from 27th Aug to 6th Nov., the last possible date prior to olives harvest.

To assess infestation level, 40 random handpicked fruits were collected from each olive tree ( 5 trees per cultivar; 200 fruits) in the mentioned periods and inspected in a binocular stereomicroscope for signs of infestation (oviposition sites or exit holes). Infestation level was expressed as the percentage of infested olives.

Simultaneously, in the same olives collected for infestation level determination, maturation index was assessed as described by Hermoso et al. (2001). Briefly, olives were classified into 8 maturation indexes (MI) based on epidermis and pulp color (0-7). Therefore, the fruit is classified as "MI 0 " if the epidermis is green; "MI 1" for yellowish green; "MI 2" if the epidermis shows red spots in less than half fruit; "MI 3 " if the epidermis is red or purple in more than half fruit; "MI 4" for black epidermis and white pulp; "MI 5" if the epidermis is black and less than half pulp is purple; "MI 6" if the epidermis is black and more than half pulp purple (without reaching the stone); "MI 7" if the epidermis is black and total pulp purple (reaching the stone). The maturation index was calculated as follows: $\mathrm{MI}=(a \times 0+b \times 1+c \times 2+d \times 3+e \times 4+f \times 5+g \times 6+h \times 7) / n$, where the letters are the number of fruits in each MI of classification considered, and $n$ is the number of olives assessed.

\subsection{Olives and leaves biometric parameters}

For biometric parameters measurements only healthy olives and leaves were considered. Per olive tree and cultivar 40 olives and leaves (200 in total) were collected during six sampling dates (27th Aug; 12th Sep; 24th Sep; 10th Oct; 23rd Oct; and 6th Nov). Parameters evaluated in leaves were: length, width and weight. Parameters evaluated in olives were: weight, maximum diameter $\left(D_{\max }\right)$, minimum diameter $\left(D_{\min }\right)$, and length. From these parameters, olives volume (according to Burrack et al., 2011) and elongation (according to Rizzo et al., 2012) were calculated. Volume was calculated according the following formula: volume $\left(\mathrm{cm}^{3}\right)=\left(\pi \times\right.$ length $\left.\times D_{\max ^{2}}{ }^{2}\right) / 6$. Elongation was calculated as the ratio between $D_{\max }$ and $D_{\min }$.

\subsection{Olives and leaves color determination}

Color from healthy olives and leaves from cvs. Cobrançosa, Madural and Verdeal Transmontana was measured with a Konica Minolta model CR-400 colorimeter. From each olive tree and cultivar 40 olives and leaves were collected (total of 200) at the same six sampling dates (27th Aug; 12th Sep; 24th Sep; 10th Oct; 23rd Oct; and 6th Nov). For each olive and leave 4 measurements were taken (with $90^{\circ}$ of distance each in olive). The monochromatic variables $L^{*}, a^{*}$ and $b^{*}$ obtained from CIELAB method were measured. $L^{*}$ is a measure of luminance or lightness component, which ranges from 0 to 100 (black and white); $a^{*}$ ranges from negative to positive (green to red respectively); $b^{*}$ also ranges from negative to positive (blue to yellow).

\subsection{Fatty acids determination}

For the fatty acids profile healthy olives from cvs. Cobrançosa, Madural and Verdeal Transmontana were separated by maturation indices from 0 to 3, according to the methodology of Hermoso et al. (2001) previously described. Olive fat was extracted in triplicate per cultivar and maturation index by a Soxhlet apparatus: $5 \mathrm{~g}$ of olive pulp smashed under sodium sulphate anhydrous, and extracted with petroleum ether during a minimum period of $24 \mathrm{~h}$ (AOAC, 2000). Fat extracted was then stored at $-20^{\circ} \mathrm{C}$ for further fatty acids profile determination according to Malheiro et al. (2012) and Commission Regulation 2568/91 (1991). The fatty acid profile was determined with a Chrompack CP 9001 chromatograph equipped with a split-splitless injector, a FID detector, an autosampler Chrompack CP-9050 and a $50 \mathrm{~m} \times 0.25 \mathrm{~mm}$ i.d. fused silica capillary column coated with a $0.19 \mu$ film of CP-Sil 88 (Varian). Helium was used as carrier gas at an internal pressure of $110 \mathrm{kPa}$. The temperatures of the detector and injector were $250^{\circ} \mathrm{C}$ and $230^{\circ} \mathrm{C}$, respectively. The oven temperature was programmed at $120^{\circ} \mathrm{C}$ during the first $3 \mathrm{~min}$ with an increase of $4^{\circ} \mathrm{C} / \mathrm{min}$ until $220^{\circ} \mathrm{C}$. The split ratio was $1: 50$ and the injected volume was of $1 \mu \mathrm{l}$. The results are expressed in relative percentage of each fatty acid, calculated by internal normalization of the chromatographic peak area eluting between myristic and lignoceric methyl esters. A control sample (olive oil 47,118, Supelco) and a fatty acids methyl esters standard mixture (Supelco 37 FAME Mix) were used for identification and calibration purposes (Sigma, Spain).

\subsection{Statistical analysis}

\subsubsection{Analysis of variance}

An analysis of variance (ANOVA) with Type III sums of squares was performed using the GLM (General Linear Model procedure) of the SPSS software, version 21.0 (IBM Corporation, New York, U.S.A.). The fulfilment of the ANOVA requirements, namely the normal distribution of the residuals and the homogeneity of variance, were evaluated by means of the Kolmogorov-Smirnov with Lilliefors correction (if $n>50$ ) or the Shapiro-Wilk's test (if $n<50$ ), and the Leveneís tests, respectively. All dependent variables were analysed using a one-way ANOVA with or without Welch correction, depending if the requirement of the homogeneity of variances was fulfilled or not. The main factors studied were: the effect of cultivar and sampling date on the physical parameters (biometrical parameters and color) of olives and leaves, and fatty acids profile of olives from cvs. Cobrançosa, Madural, and Verdeal Transmontana. If a statistical significant effect was found, means were compared using Tukeyís honestly significant difference multiple comparison test or 
Dunnett T3 test also depending if equal variances could be assumed or not. All statistical tests were performed at a 5\% significance level.

\subsubsection{Principal component analysis}

Principal components analysis (PCA) was applied for reducing the number of variables in the color parameters of olives and olive leaves (upper page) of the three olive cultivars to a smaller number of new derived variables (principal component or factors) that adequately summarize the original information, i.e., the effect of maturation in color parameters of olives and olive leaves from cvs. Cobrançosa, Madural and Verdeal Transmontana. Overall 6 variables corresponding to the $L^{*}, a^{*}$ and $b^{*}$ from olives and olive leaves were used in PCA. Moreover, it allowed recognizing patterns in the data by plotting them in a multidimensional space, using the new derived variables as dimensions (factor scores). PCA was performed by using SPSS software, version 21.0 (IBM Corporation, New York, U.S.A.).

\section{Results and discussion}

\subsection{Infestation levels and maturation}

Olive fly infestation levels in the three cultivars studied are represented in Fig. 1.

From a general analysis cv. Verdeal Transmontana is the most susceptible olive cultivar reporting maximum infestation levels of 24.5\%, cv. Madural with 17.5\% (23rd Oct.), while cv. Cobrançosa olives were the less susceptible to olive fly, with maximum levels of $8.5 \%$. From 27th Aug. until 10th Oct. infestation was similar in the three cultivars. After that date infestation intensely, mainly in the two most susceptible olive cultivars. In cv. Cobrançosa olives the infestation levels also increased but in lower extent. At the end of the study (6th Nov.) the infestation levels were significantly different between cv. Verdeal Transmontana and Cobrançosa $(P=0.030)$, while at the remaining sampling dates no statistical differences were observed $(P>0.05)$. The results obtained clarify that with the time course, olives infestation level among cvs. Cobrançosa and Verdeal Transmontana increases, and that from the later is increasingly preferred by olive females. These results were also observed by Gonçalves et al. (2012) and Malheiro et al. (2015) by studying the infestation levels of these three olive cultivars, however with much higher infestation levels in previous seasons. In the mentioned works, the olive fly preference towards cvs. Verdeal Transmontana and Madural, in detriment of cv. Cobrançosa, was also verified.

Oviposition preference of olive fly may be related to physical parameters of olive tree (both fruits and olive leaves), some of which directly related to maturation process, that inflict considerable changes in olives physical parameters (biometrical parameters and color as well). Fig. 2 displays the maturation indices from the three olive cultivars in study during this crop season.

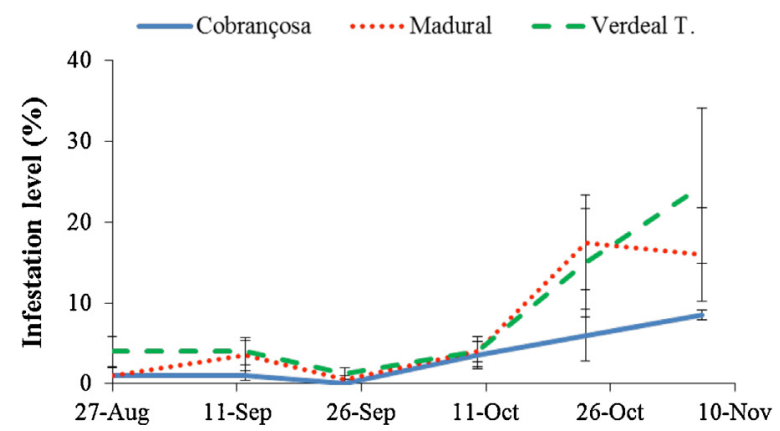

Fig. 1. Infestation levels (\%) of olives from cvs. Cobrançosa, Madural and Verdeal Transmontana.
Visually, it is easily perceived that cv. Cobrançosa has a faster maturation process, with olives becoming reddish in the last week of October $(\mathrm{MI}=2.1)$, and being completely reddish soon, in the first week of November $(\mathrm{MI}=3.0)$. Comparatively, cv. Verdeal Transmontana olives remained green or yellow-green during the entire study (Fig. 1). Olives from cv. Madural revealed an intermedium maturation process, with a MI of 2.0 at the end of the study (Fig. 2). Therefore physical changes as well as appearance of olives are considerably changed during maturation. In the following section olives and leaves color is discussed regarding olive fly oviposition preference.

\subsection{Color of olives and olive leaves}

The monochromatic variables $L^{*}, a^{*}$ and $b^{*}$ are detailed in Table 1 .

Regarding the olives color, both cultivar and sampling date influenced the results obtained. Regarding lightness $\left(L^{*}\right)$, olives from cv. Cobrançosa increase continuously until 10th Oct, when olives are yellow-green $\left(L^{*}=58.0\right)$. After that, when maturation start to advance towards reddish tones, lightness reduced significantly to 46.0 at 23 rd Oct., and to 35.2 at 6 th Nov. (Table 1 ). Olives from cv. Madural reported an increment until 23rd Oct $\left(L^{*}=54.9\right)$ decreasing then to 6th $\operatorname{Nov}\left(L^{*}=50.7\right)$, corresponding to the time in which olives also started to change color to reddish tones (Fig. 2). Nevertheless, olives from cv. Verdeal Transmontana reported always higher lightness values, and it increased during the entire study from 52.1 at first sampling date (27th Aug) to 59.8 at the last sampling date (6th Nov). From the results obtained, and interpreting them according to the results from Fig. 1, lightness increased during olives maturation from green $(\mathrm{MI}=0)$ to yellow-green olives $(\mathrm{MI}=1)$, reducing sharply when olives start changing to reddish tones ( $\mathrm{MI}=2$ and 3 ).

The other two monochromatic parameters are also in accordance with Fig. 1. Concerning $a^{*}$ values cv. Cobrançosa olives are less green than cv. Madural and Verdeal Transmontana. Olives from cv. Cobrançosa loss their green coloration at 23rd Oct $\left(a^{*}=1.7\right)$ and become clearly red at 6 th $\operatorname{Nov}\left(a^{*}=6.8\right)$. Olives from $\mathrm{cv}$. Madural lost their green coloration sooner, with $a^{*}$ values ranging between -18.6 (27th Aug) and -8.7 (6th Nov), corresponding this last value to the changing color stage. Olives from cv. Verdeal Transmontana maintained a green coloration (Fig. 1), therefore with higher $a^{*}$ values comparatively to both Cobrançosa and Madural olives (Table 1). A curious observation was that $a^{*}$ values from cv. Verdeal Transmontana olives at the last sampling date were higher than those reported by cv. Cobrançosa olives at the first sampling date, attesting the characteristically slow maturation process of this cultivar.

Concerning $b^{*}$ values they decreased in olives from cvs. Cobrançosa and Madural, with higher loss in Cobrançosa olives (Table 1). Olives from cv. Verdeal Transmontana maintained their yellow-green coloration (Fig. 1) up to olives harvest time.

Olive leaves color was recorded on both upper and down pages. Down pages have a lighter green, while upper pages are greener. Small $L^{*}$ values variations were found in the three olive cultivars during crop season in the leaves down pages, varying between 65.9 and 69.3. Small variations were also observed in $a^{*}$ values during crop season, ranging between -6.3 and -7.6 . Values of $b^{*}$ decreased consistently during the entire studied season, from 15.0 to 13.5 in cv. Cobrançosa, from 14.6 to 12.4 in cv. Madural, and from 14.8 to 12.7 in cv. Verdeal Transmontana (Table 1). In the leaves upper pages all $L^{*}, a^{*}$ and $b^{*}$ values decrease during crop season. In a general way, olive leaves from cv. Verdeal Transmontana reported always higher values of the three color parameters measured during the entire study. Again, like in olives, $L^{*}$ values, were higher in the most susceptible olive cultivar. These observations, both in olives and olive leaves could be related to the epicuticular waxes composition of each olive cultivar. Epicuticu- 


\section{Cultivar}

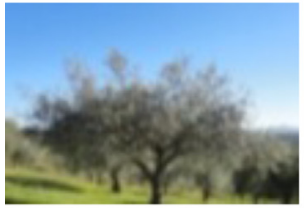

Cobrançosa

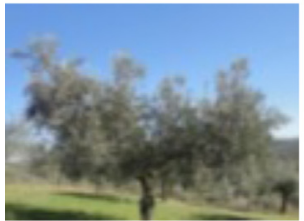

Madural

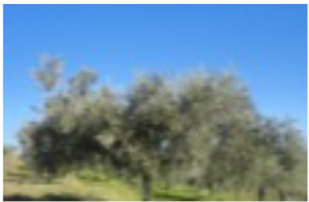

Verdeal Transmontana $27^{\text {th }}$ Aug

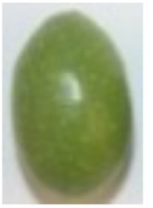

0

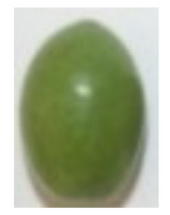

0

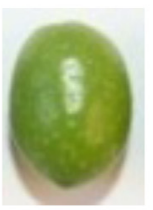

0

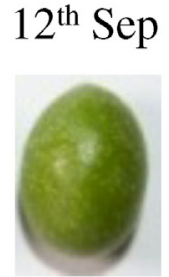

0

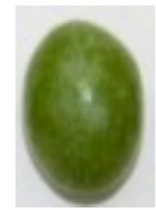

0.1

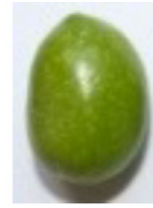

0.1

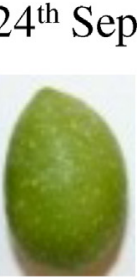

0.3

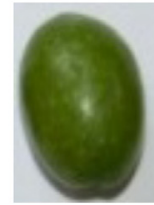

0.3

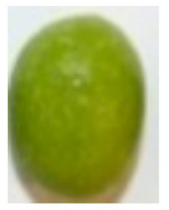

0.2

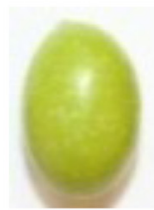

0.8

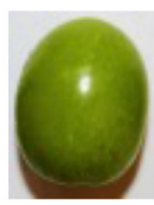

0.6

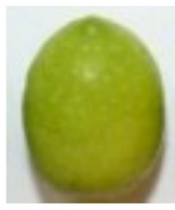

0.6 $23^{\text {rd }}$ Oct

$6^{\text {th }} \mathrm{Nov}$

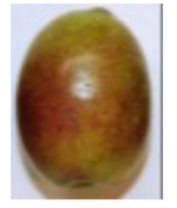

2.1

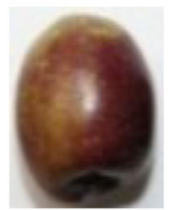

3.0
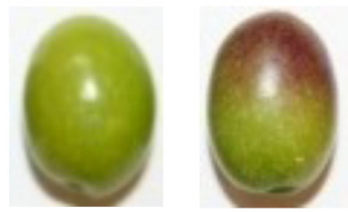

0.7

2.0

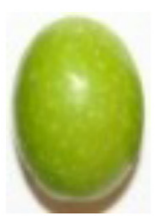

0.7

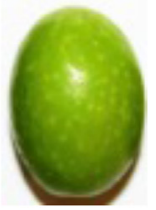

0.9

Fig. 2. Maturation index of olives from cvs. Cobrançosa, Madural and Verdeal Transmontana during olive crop season.

Table 1

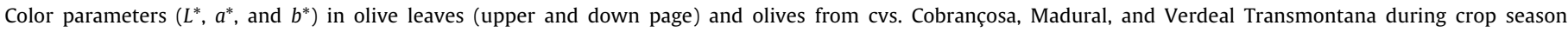
( mean \pm standard deviation; $\mathrm{n}=200$ ).

\begin{tabular}{|c|c|c|c|c|c|c|c|c|c|}
\hline \multirow[t]{2}{*}{ Olives } & \multicolumn{3}{|l|}{$L^{*}$} & \multicolumn{3}{|l|}{$a^{*}$} & \multicolumn{3}{|l|}{$b^{*}$} \\
\hline & Cobrançosa & Madural & Verdeal T. & Cobrançosa & Madural & Verdeal T. & Cobrançosa & Madural & Verdeal T. \\
\hline 27th Aug. & $50.8 \pm 0.9 \mathrm{bC}$ & $50.2 \pm 0.7 \mathrm{aA}$ & $52.1 \pm 1.4 \mathrm{cA}$ & $-17.6 \pm 0.5 \mathrm{cA}$ & $-18.6 \pm 0.2 \mathrm{bA}$ & $-19.3 \pm 0.1 \mathrm{aB}$ & $32.2 \pm 0.8 \mathrm{aD}$ & $32.5 \pm 0.4 \mathrm{bB}$ & $34.8 \pm 0.6 \mathrm{cA}$ \\
\hline 12th Sep. & $52.8 \pm 0.2 \mathrm{bD}$ & $52.4 \pm 0.5 \mathrm{aB}$ & $53.9 \pm 1.6 \mathrm{cB}$ & $-16.6 \pm 0.7 \mathrm{cB}$ & $-18.3 \pm 0.8 \mathrm{bA}$ & $-18.8 \pm 0.6 \mathrm{aC}$ & $30.6 \pm 1.1 \mathrm{aC}$ & $32.5 \pm 1.7 \mathrm{bB}$ & $34.7 \pm 1.7 \mathrm{cA}$ \\
\hline 24th Sep. & $53.2 \pm 1.3 \mathrm{bD}$ & $52.8 \pm 0.6 \mathrm{aB}$ & $53.7 \pm 0.5 \mathrm{cB}$ & $-16.3 \pm 1.3 \mathrm{cB}$ & $-18.1 \pm 0.7 \mathrm{bAB}$ & $-18.6 \pm 1.6 \mathrm{aC}$ & $32.5 \pm 1.5 \mathrm{aD}$ & $33.2 \pm 1.8 \mathrm{bB}$ & $35.4 \pm 3.6 \mathrm{cA}$ \\
\hline 10th Oct. & $58.0 \pm 0.6 \mathrm{bE}$ & $55.3 \pm 0.8 \mathrm{aC}$ & $57.9 \pm 2.1 \mathrm{bC}$ & $-17.9 \pm 1.3 \mathrm{cA}$ & $-18.7 \pm 0.6 \mathrm{bA}$ & $-19.9 \pm 0.1 \mathrm{aA}$ & $37.3 \pm 1.9 \mathrm{bE}$ & $36.5 \pm 0.9 \mathrm{aD}$ & $39.1 \pm 2.1 \mathrm{cD}$ \\
\hline 23rd Oct. & $46.0 \pm 5.9 \mathrm{aB}$ & $54.9 \pm 2.0 \mathrm{bC}$ & $58.9 \pm 1.6 \mathrm{cD}$ & $1.7 \pm 0.3 \mathrm{cC}$ & $-17.5 \pm 0.3 \mathrm{bB}$ & $-20.0 \pm 0.6 \mathrm{aA}$ & $18.1 \pm 2.3 \mathrm{aB}$ & $34.6 \pm 3.4 \mathrm{bC}$ & $38.3 \pm 1.4 \mathrm{cC}$ \\
\hline 6th Nov. & $35.2 \pm 6.8 \mathrm{aA}$ & $50.7 \pm 2.2 \mathrm{bA}$ & $59.8 \pm 1.1 \mathrm{cE}$ & $6.8 \pm 0.9 \mathrm{cD}$ & $-8.7 \pm 3.5 \mathrm{bC}$ & $-18.0 \pm 2.3 \mathrm{aD}$ & $7.5 \pm 4.5 \mathrm{aA}$ & $27.9 \pm 3.3 \mathrm{bA}$ & $37.8 \pm 0.9 \mathrm{cB}$ \\
\hline \multicolumn{10}{|c|}{ Leaves down page } \\
\hline 27th Aug. & $67.0 \pm 8.4 \mathrm{bB}$ & $67.9 \pm 2.6 \mathrm{abBC}$ & $67.5 \pm 1.7 \mathrm{aBC}$ & $-7.1 \pm 1.3 \mathrm{bB}$ & $-6.4 \pm 1.7 \mathrm{cC}$ & $-7.5 \pm 0.8 \mathrm{aA}$ & $15.0 \pm 2.2 \mathrm{bD}$ & $14.6 \pm 2.4 \mathrm{aD}$ & $14.8 \pm 1.4 \mathrm{abD}$ \\
\hline 12th Sep. & $68.3 \pm 1.7 \mathrm{aA}$ & $69.3 \pm 2.2 \mathrm{cE}$ & $67.1 \pm 2.2 \mathrm{bBC}$ & $-7.3 \pm 0.8 \mathrm{aA}$ & $-7.1 \pm 1.3 \mathrm{bA}$ & $-7.6 \pm 0.7 \mathrm{aA}$ & $14.6 \pm 1.2 \mathrm{aCD}$ & $14.6 \pm 2.0 \mathrm{aD}$ & $14.7 \pm 1.4 \mathrm{aCD}$ \\
\hline 24th Sep. & $68.5 \pm 1.6 \mathrm{aB}$ & $68.4 \pm 2.0 \mathrm{bD}$ & $69.2 \pm 2.3 \mathrm{bC}$ & $-7.1 \pm 0.9 \mathrm{aBC}$ & $-6.5 \pm 1.2 \mathrm{bB}$ & $-6.9 \pm 1.0 \mathrm{abBC}$ & $14.9 \pm 1.6 \mathrm{bBC}$ & $13.2 \pm 1.6 \mathrm{aC}$ & $14.6 \pm 2.0 \mathrm{bCD}$ \\
\hline 10th Oct. & $66.2 \pm 2.7 \mathrm{aA}$ & $67.8 \pm 2.2 \mathrm{bCD}$ & $66.7 \pm 6.7 \mathrm{aB}$ & $-7.4 \pm 1.2 \mathrm{aAB}$ & $-6.8 \pm 0.8 \mathrm{bB}$ & $-7.2 \pm 1.2 \mathrm{aB}$ & $14.2 \pm 1.5 \mathrm{bB}$ & $13.1 \pm 1.2 \mathrm{aB}$ & $14.2 \pm 2.3 \mathrm{bC}$ \\
\hline 23rd Oct. & $66.6 \pm 1.6 \mathrm{aA}$ & $66.6 \pm 2.5 \mathrm{aA}$ & $66.5 \pm 1.6 \mathrm{aB}$ & $-6.8 \pm 0.8 \mathrm{aD}$ & $-6.5 \pm 1.0 \mathrm{bC}$ & $-6.9 \pm 0.7 \mathrm{aC}$ & $13.5 \pm 0.9 \mathrm{bA}$ & $12.8 \pm 1.8 \mathrm{aAB}$ & $13.8 \pm 1.1 \mathrm{bB}$ \\
\hline 6th Nov. & $66.8 \pm 1.4 \mathrm{bA}$ & $67.0 \pm 2.0 \mathrm{bAB}$ & $65.9 \pm 2.1 \mathrm{aA}$ & $-6.8 \pm 0.6 \mathrm{aCD}$ & $-6.4 \pm 0.7 b C$ & $-6.3 \pm 0.9 \mathrm{bD}$ & $13.5 \pm 0.9 \mathrm{bA}$ & $12.4 \pm 1.1 \mathrm{aA}$ & $12.7 \pm 1.7 \mathrm{aA}$ \\
\hline \multicolumn{10}{|c|}{ Leaves Upper page } \\
\hline 27th Aug. & $42.6 \pm 2.5 \mathrm{bC}$ & $41.7 \pm 4.2 \mathrm{aD}$ & $44.1 \pm 3.3 \mathrm{cBC}$ & $-9.0 \pm 1.8 \mathrm{cA}$ & $-9.8 \pm 2.2 \mathrm{bB}$ & $-10.9 \pm 1.6 \mathrm{aA}$ & $12.4 \pm 2.6 \mathrm{aD}$ & $13.9 \pm 3.4 b D$ & $15.3 \pm 2.9 \mathrm{cD}$ \\
\hline 12th Sep. & $43.3 \pm 3.7 \mathrm{bD}$ & $42.2 \pm 2.5 \mathrm{aD}$ & $43.6 \pm 3.9 \mathrm{bBC}$ & $-8.5 \pm 1.5 \mathrm{cB}$ & $-10.7 \pm 1.8 \mathrm{aA}$ & $-9.2 \pm 1.6 \mathrm{bB}$ & $11.7 \pm 2.3 \mathrm{aD}$ & $14.7 \pm 2.7 \mathrm{cE}$ & $12.1 \pm 2.3 \mathrm{bB}$ \\
\hline 24th Sep. & $42.6 \pm 3.1 \mathrm{bC}$ & $40.4 \pm 3.2 \mathrm{aC}$ & $46.7 \pm 5.0 \mathrm{cD}$ & $-8.2 \pm 1.6 \mathrm{bC}$ & $-9.3 \pm 2.2 \mathrm{aB}$ & $-9.8 \pm 2.0 \mathrm{aB}$ & $11.5 \pm 2.3 \mathrm{aC}$ & $12.7 \pm 2.7 \mathrm{bC}$ & $14.6 \pm 3.3 \mathrm{bC}$ \\
\hline 10th Oct. & $41.2 \pm 4.1 \mathrm{bB}$ & $39.6 \pm 2.4 \mathrm{aB}$ & $43.9 \pm 6.7 \mathrm{cB}$ & $-7.4 \pm 1.4 \mathrm{bD}$ & $-9.1 \pm 1.1 \mathrm{aB}$ & $-9.6 \pm 2.0 \mathrm{aB}$ & $9.6 \pm 1.7 \mathrm{aB}$ & $11.6 \pm 1.5 \mathrm{bB}$ & $13.3 \pm 3.3 \mathrm{cB}$ \\
\hline 23rd Oct. & $39.8 \pm 2.0 \mathrm{bA}$ & $38.0 \pm 1.9 \mathrm{aA}$ & $40.6 \pm 2.4 \mathrm{cA}$ & $-6.0 \pm 1.0 \mathrm{bE}$ & $-7.2 \pm 1.1 \mathrm{aC}$ & $-7.3 \pm 0.9 \mathrm{aC}$ & $7.6 \pm 1.2 \mathrm{aA}$ & $9.0 \pm 1.4 \mathrm{cA}$ & $8.9 \pm 1.2 \mathrm{bA}$ \\
\hline 6th Nov. & $40.1 \pm 2.1 \mathrm{bAB}$ & $37.3 \pm 1.9 \mathrm{aA}$ & $41.9 \pm 4.5 \mathrm{cCD}$ & $-6.0 \pm 1.1 \mathrm{bE}$ & $-7.2 \pm 0.8 \mathrm{aC}$ & $-6.3 \pm 1.3 \mathrm{bD}$ & $7.7 \pm 1.3 \mathrm{Aa}$ & $8.7 \pm 1.0 \mathrm{bA}$ & $7.7 \pm 1.7 \mathrm{abA}$ \\
\hline
\end{tabular}

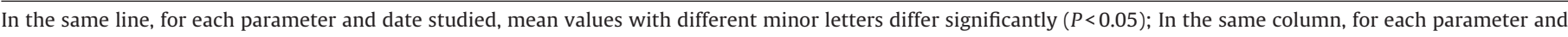
cultivar studied, mean values with different capital letters differ significantly $(P<0.05)$.

lar waxes could intervene in a decisive way in olive fly preference towards cv. Verdeal Transmontana. Neuenschwander et al. (1985), a pioneer in the study of susceptibility of olive cultivars to olive fly, reported that surface covering could decisively influence olive fly. Later, Kombargi et al. (1998) verified that superficial waxes of olives reduced by half the number of eggs laid in olives from Greek cultivars. Furthermore, the total amount and profiles of epicuticular waxes in both olives and leaves are cultivar dependent (Guinda et al., 2010) and during maturation they decrease mainly in olives
(Peragón, 2013). Therefore the loss of lightness in both olives and leaves could be related to epicuticular waxes, and this aspect could influence olive fly oviposition, being interesting to explore in future studies. Significant differences were found among cultivars in some color parameters, but a higher impact of cultivar was observed in the upper pages of olive leaves.

The color parameters evaluated on both olives and leaves presented different characteristic on each olive cultivar at a determined date assessed. By applying a PCA to the data related to olives 


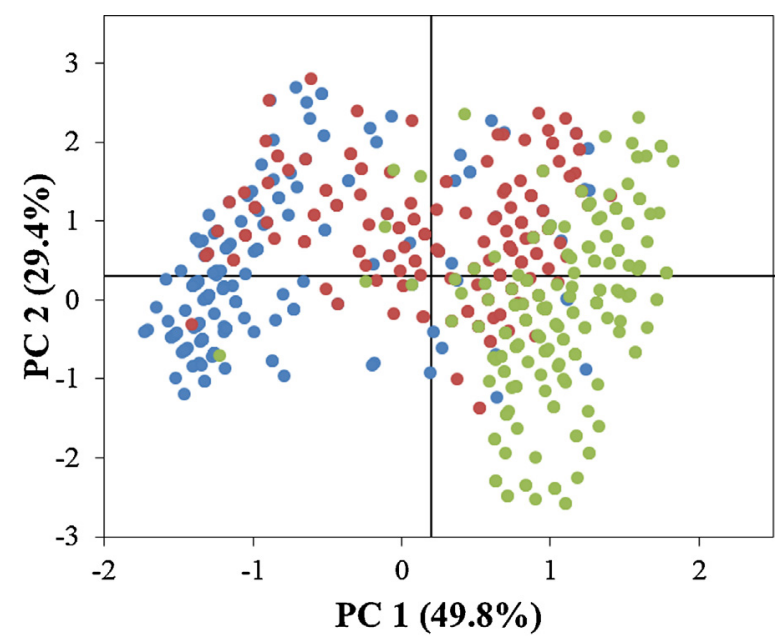

- Cobrançosa - Madural - Verdeal T.

Fig. 3. Principal component analysis obtained from the color parameters $\left(L^{*} a^{*}\right.$, and $b^{*}$ ) of olive leaves upper page and olives from cvs. Cobrançosa, Madural, and Verdeal Transmontana at the last date studied (6th Nov). Principal components explain $79.2 \%$ of the total variance.

and olive leaves (upper page) color parameters at the last assessed date and we verify that three main groups are created (Fig. 3). In Fig. 3 it is possible to observe that cv. Verdeal olives and leaves (positive region of PC 1) are clearly different from those of $\mathrm{cV}$. Cobrançosa (negative region of PC 1).

Olives and leaves from cv. Madural are placed among the more and less susceptible olive cultivars.

Therefore, in field conditions, when olive fly attacks become more intense, olive fly has olives with different colors, since cultivars present different maturation rates. Indeed, when all olives were green the infestation is quite similar in the three cultivars. Infestation levels started to differentiate among cultivars at the two last sampling dates, corresponding to the progress of maturation (Fig. 1). Color parameters corroborate results verified in Fig. 1, therefore olive fly may be attracted to green and greenyellow fruits, while olives at higher maturation stages $(\mathrm{MI}=3$ or superior) may be less preferred to oviposit if in the presence of green or yellow-green ones. This could justify the high preference of olive fly to cv. Verdeal Transmontana olives, and less preference towards cv. Cobrançosa. In fact, it was already observed in other cultivars that infestation odds decrease from green to reddish fruits (Rizzo et al., 2012). Even more, olive fly females are attracted to yellow and green colorations to oviposit rather than red or dark colors (Katsoyannos et al., 1985). Nevertheless, some other physical parameters can also be correlated with oviposition preference, as discussed in the next section.

\subsection{Physical parameters of olives and olive leaves}

In general, leaves from cv. Cobrançosa presented a slightly lower length, varying between 7.01 and $7.30 \mathrm{~cm}$, while cv. Madural varied from 7.00 to $7.45 \mathrm{~cm}$, and those from cv. Verdeal Transmontana ranged from 7.05 to $7.36 \mathrm{~cm}$ (Table 2).

Regarding width, cv. Madural leaves are wider than the other two cultivars $(1.13-1.35 \mathrm{~cm})$. Cobrançosa have a width of $1.02-1.11 \mathrm{~cm}$ while $\mathrm{cv}$. Verdeal Transmontana reported only $0.93-1.03 \mathrm{~cm}$ (Table 2). Concerning weight, cv. Madural reported the heaviest leaves with mass between $0.25-0.30 \mathrm{~g}$, while cvs. Cobrançosa and Verdeal Transmontana ranged between $0.20-0.22 \mathrm{~g}$ and $0.19-0.21 \mathrm{~g}$, respectively. Apparently, olive leaves physical parameters evaluated may not be decisive in the oviposition preference of olive fly. However, the lower leaves width observed in Verdeal Transmostana could constitute favorable parameters for olive fly penetration into the olives branches. However, in future works the curvature of leaves and their shape should be considered since it may reflect light in a different way that could cause any change in the behavior and choice of olive fly. The leaves density per branches could also be a parameter to take into account, since they could offer shelter and protection to olive flies.

The biometrical data collected on olives are reported in Table 3.

All the biometrical parameters increased as function of the maturation progress and fruit development. Concerning olives volume, cv. Verdeal Transmontana reported significant higher volume in two dates assessed, 24th Sep and 6th Nov (Table 3). This is an important observation since a direct relation between olives volume and infestation level has already been clearly established (Rizzo et al., 2012). Another important information is olives elongation, which is negatively correlated with infestation level (Rizzo et al., 2012). In our cultivars the two most susceptible cultivars (Madural and Verdeal Transmontana) reported also lower elongation values than cv. Cobrançosa.

\subsection{Olives fatty acids profile}

Regardless of olive cultivar and maturation index, oil was mainly composed by oleic acid $\left(\mathrm{C}_{18: 1}\right)$ as characteristic from olive oil. This monounsaturated fatty acid was present in higher amounts in cv. Verdeal Transmontana, fruits with values ranging from $78.0 \%$ (at $\mathrm{MI}=0$ ) to $80.4 \%$ (at $\mathrm{MI}=3$ ) in an opposite tendency to cvs. Cobrançosa and Madural, where oleic acid decreased during maturation, from 75.0 to $73.7 \%$ and from 73.5 to $70.2 \%$, respectively (Table 4).

Palmitic acid $\left(\mathrm{C}_{16: 0}\right)$ was the second main fatty acid, with constant values during maturation in cv. Cobrançosa, a slight increase in cv. Madural, and a pronounced decreased in cv. Verdeal Transmontana. Important differences were observed in linoleic acid $\left(C_{18: 2}\right)$ relative amounts, increasing considerably during maturation on both cvs. Cobrançosa and Madural, while in cv. Verdeal Transmontana it decreases. In cv. Verdeal Transmonta linoleic acid varied between 3.25 and $2.34 \%$, far below the minimum values of cv. Cobrançosa 5.57\%. In cv. Madural linoleic acid reported high values ranging from 8.20 to $11.53 \%$. Globally, the polyunsaturated (PUFA) fatty acids content was significantly lower in cv. Verdeal Transmontana.

The characteristic fatty acids composition found in olives of the three olive cultivars may play an important role in olive fly oviposition. When olive fly females oviposit, the penetration of ovipositor in olive pulp may perceive the medium in which they will lay their eggs, since ovipositor is composed by chemosensilla (Zhang et al., 2012). This specific perception organ is composed by receptor neurons. In this particular case the amount of fat, higher in cv. Verdeal Transmontana (Gonçalves et al., 2012), as well as its composition, particularly the lower PUFA content, may decisively influence olive fly to lay their eggs. Furthermore, fatty acids composition also could influence the survival of adults of olive fly. Since cv. Verdeal Transmontana report higher fat content (Gonçalves et al., 2012), larvae developed in their olives could accumulate higher amounts of fat in their organism, reserves that will pass to adults and that could satisfy the nutritional requirements of adults for longer periods. The composition of the fat is other aspect that could also influence survival of adults and for other functions. For instance, fatty acids are precursors in the synthesis of pheromones, being therefore important in insects reproduction and survival (Arrese and Soulages, 2010). Regarding fatty acids, future works could be carried out to study the impact of fatty acids composition in the longevity and behavior of olive fly adults. This could lead to a higher longevity by adults, and an important ecological aspect to this pest. 
Table 2

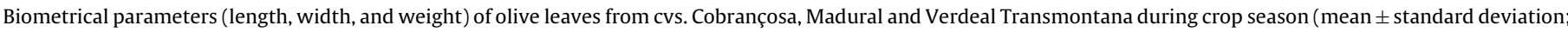
$n=200)$.

\begin{tabular}{|c|c|c|c|c|c|c|c|c|c|}
\hline & \multicolumn{3}{|l|}{ Length $(\mathrm{cm})$} & \multicolumn{3}{|l|}{ Width (cm) } & \multicolumn{3}{|l|}{ Weight (cm) } \\
\hline & Cobrançosa & Madural & Verdeal T. & Cobrançosa & Madural & Verdeal T. & Cobrançosa & Madural & Verdeal T. \\
\hline 27th Aug. & $7.01 \pm 0.42 \mathrm{aA}$ & $7.00 \pm 0.42 \mathrm{aA}$ & $7.21 \pm 0.27 \mathrm{bAB}$ & $1.02 \pm 0.04 \mathrm{bA}$ & $1.13 \pm 0.11 \mathrm{cA}$ & $0.93 \pm 0.05 \mathrm{aA}$ & $0.20 \pm 0.02 \mathrm{aA}$ & $0.25 \pm 0.02 \mathrm{bA}$ & $0.20 \pm 0.01 \mathrm{aAB}$ \\
\hline 12th Sep. & $7.15 \pm 0.50 \mathrm{aAB}$ & $7.34 \pm 0.32 \mathrm{aB}$ & $7.27 \pm 0.25 \mathrm{aB}$ & $1.09 \pm 0.03 \mathrm{bC}$ & $1.32 \pm 0.04 \mathrm{cB}$ & $1.03 \pm 0.07 \mathrm{aB}$ & $0.21 \pm 0.01 \mathrm{aAB}$ & $0.26 \pm 0.01 \mathrm{bAB}$ & $0.20 \pm 0.01 \mathrm{aBC}$ \\
\hline 24th Sep. & $7.30 \pm 0.10 \mathrm{bB}$ & $7.43 \pm 0.30 \mathrm{bB}$ & $7.13 \pm 0.26 \mathrm{aA}$ & $1.08 \pm 0.05 \mathrm{bBC}$ & $1.33 \pm 0.08 \mathrm{cB}$ & $1.01 \pm 0.15 \mathrm{aB}$ & $0.21 \pm 0.01 \mathrm{bAB}$ & $0.28 \pm 0.02 \mathrm{cB}$ & $0.19 \pm 0.00 \mathrm{aA}$ \\
\hline 10th Oct. & $7.04 \pm 0.39 \mathrm{aA}$ & $7.44 \pm 0.38 \mathrm{bB}$ & $7.36 \pm 0.21 \mathrm{bB}$ & $1.11 \pm 0.06 \mathrm{bC}$ & $1.35 \pm 0.03 \mathrm{cB}$ & $1.02 \pm 0.06 \mathrm{aB}$ & $0.22 \pm 0.02 \mathrm{aB}$ & $0.28 \pm 0.02 \mathrm{bB}$ & $0.21 \pm 0.01 \mathrm{aD}$ \\
\hline 23rd Oct. & $7.14 \pm 0.16 \mathrm{aAB}$ & $7.45 \pm 0.35 \mathrm{bB}$ & $7.32 \pm 0.19 \mathrm{bB}$ & $1.08 \pm 0.05 \mathrm{bBC}$ & $1.35 \pm 0.05 \mathrm{cB}$ & $0.99 \pm 0.07 \mathrm{aB}$ & $0.22 \pm 0.01 \mathrm{aB}$ & $0.30 \pm 0.02 b C$ & $0.21 \pm 0.02 \mathrm{aB}-\mathrm{D}$ \\
\hline 6th Nov. & $7.03 \pm 0.27 \mathrm{aA}$ & $7.32 \pm 0.32 \mathrm{bB}$ & $7.05 \pm 0.16 \mathrm{aA}$ & $1.05 \pm 0.04 \mathrm{bAB}$ & $1.31 \pm 0.11 \mathrm{cB}$ & $1.01 \pm 0.10 \mathrm{aB}$ & $0.21 \pm 0.01 \mathrm{aAB}$ & $0.28 \pm 0.03 \mathrm{bBC}$ & $0.21 \pm 0.02 \mathrm{aCD}$ \\
\hline
\end{tabular}

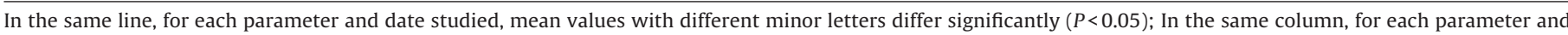
cultivar studied, mean values with different capital letters differ significantly $(P<0.05)$.

Table 3

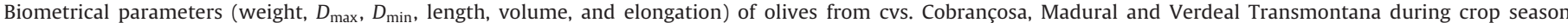
(mean \pm standard deviation; $n=200$ ).

\begin{tabular}{|c|c|c|c|c|c|c|}
\hline & \multicolumn{3}{|l|}{ Weight (g) } & \multicolumn{3}{|l|}{$D_{\max }(\mathrm{cm})$} \\
\hline & Cobrançosa & Madural & Verdeal T. & Cobrançosa & Madural & Verdeal T. \\
\hline 27th Aug. & $2.04 \pm 0.14 \mathrm{bB}$ & $1.91 \pm 0.42 \mathrm{aAB}$ & $1.96 \pm 0.24 \mathrm{abA}$ & $1.34 \pm 0.04 \mathrm{aB}$ & $1.33 \pm 0.08 \mathrm{aAB}$ & $1.33 \pm 0.11 \mathrm{aA}$ \\
\hline 12th Sep. & $1.98 \pm 0.21 \mathrm{aAB}$ & $2.03 \pm 0.43 \mathrm{aB}$ & $1.95 \pm 0.27 \mathrm{aA}$ & $1.31 \pm 0.07 \mathrm{aAB}$ & $1.34 \pm 0.11 \mathrm{bB}$ & $1.35 \pm 0.11 \mathrm{bA}$ \\
\hline 24th Sep. & $1.87 \pm 0.20 \mathrm{aA}$ & $1.89 \pm 0.27 \mathrm{aA}$ & $1.92 \pm 0.43 \mathrm{aA}$ & $1.28 \pm 0.06 \mathrm{aA}$ & $1.31 \pm 0.09 \mathrm{abA}$ & $1.32 \pm 0.15 \mathrm{bA}$ \\
\hline 10th Oct. & $2.86 \pm 0.74 \mathrm{cC}$ & $2.35 \pm 0.29 \mathrm{aC}$ & $2.54 \pm 0.37 \mathrm{bB}$ & $1.55 \pm 0.15 \mathrm{bD}$ & $1.43 \pm 0.07 \mathrm{aC}$ & $1.51 \pm 0.11 \mathrm{bB}$ \\
\hline 23rd Oct. & $2.76 \pm 0.20 \mathrm{bC}$ & $2.39 \pm 0.33 \mathrm{aC}$ & $2.65 \pm 0.12 \mathrm{bB}$ & $1.51 \pm 0.04 \mathrm{bC}$ & $1.45 \pm 0.08 \mathrm{aC}$ & $1.52 \pm 0.05 \mathrm{bB}$ \\
\hline \multirow[t]{3}{*}{ 6th Nov. } & $2.86 \pm 0.15 \mathrm{bC}$ & $2.67 \pm 0.33 \mathrm{aD}$ & $2.84 \pm 0.31 \mathrm{bC}$ & $1.51 \pm 0.02 \mathrm{aCD}$ & $1.49 \pm 0.07 \mathrm{aD}$ & $1.56 \pm 0.09 \mathrm{bC}$ \\
\hline & \multicolumn{3}{|l|}{$D_{\min }(\mathrm{cm})$} & \multicolumn{3}{|l|}{ Length $(\mathrm{cm})$} \\
\hline & Cobrançosa & Madural & Verdeal T. & Cobrançosa & Madural & Verdeal T. \\
\hline 27th Aug. & $0.70 \pm 0.02 \mathrm{aB}$ & $0.74 \pm 0.05 \mathrm{bD}$ & $0.74 \pm 0.09 \mathrm{bC}$ & $1.97 \pm 0.04 \mathrm{Ab}$ & $1.89 \pm 0.09 \mathrm{aA}$ & $1.92 \pm 0.06 \mathrm{aA}$ \\
\hline 12th Sep. & $0.61 \pm 0.04 \mathrm{aB}$ & $0.69 \pm 0.07 \mathrm{cC}$ & $0.63 \pm 0.07 \mathrm{bB}$ & $1.96 \pm 0.05 \mathrm{bA}$ & $1.90 \pm 0.11 \mathrm{aA}$ & $1.94 \pm 0.05 \mathrm{bA}$ \\
\hline 24th Sep. & $0.56 \pm 0.04 \mathrm{aB}$ & $0.62 \pm 0.07 \mathrm{bA}$ & $0.57 \pm 0.09 \mathrm{aA}$ & $1.94 \pm 0.04 \mathrm{bA}$ & $1.86 \pm 0.04 \mathrm{aA}$ & $1.95 \pm 0.08 \mathrm{bA}$ \\
\hline 10th Oct. & $0.67 \pm 0.12 \mathrm{aB}$ & $0.63 \pm 0.03 \mathrm{aAB}$ & $0.64 \pm 0.03 \mathrm{aB}$ & $2.11 \pm 0.11 \mathrm{aB}$ & $1.97 \pm 0.07 \mathrm{cB}$ & $2.07 \pm 0.05 \mathrm{bB}$ \\
\hline 23rd Oct. & $0.63 \pm 0.02 \mathrm{aB}$ & $0.64 \pm 0.03 \mathrm{aB}$ & $0.64 \pm 0.04 \mathrm{aB}$ & $2.10 \pm 0.75 b B$ & $1.96 \pm 0.09 \mathrm{aB}$ & $2.09 \pm 0.04 \mathrm{bBC}$ \\
\hline \multirow[t]{3}{*}{ 6th Nov. } & $0.60 \pm 0.04 \mathrm{aB}$ & $0.63 \pm 0.03 \mathrm{bAB}$ & $0.62 \pm 0.04 \mathrm{bAB}$ & $2.12 \pm 0.03 \mathrm{bB}$ & $2.03 \pm 0.06 \mathrm{aC}$ & $2.13 \pm 0.05 b C$ \\
\hline & \multicolumn{3}{|l|}{ Volume $\left(\mathrm{cm}^{3}\right)$} & \multicolumn{3}{|l|}{ Elongation } \\
\hline & Cobrançosa & Madural & Verdeal T. & Cobrançosa & Madural & Verdeal T. \\
\hline 27th Aug. & $1.86 \pm 0.15 \mathrm{aA}$ & $1.79 \pm 0.30 \mathrm{aAB}$ & $1.81 \pm 0.33 \mathrm{aA}$ & $1.47 \pm 0.04 \mathrm{aC}$ & $1.43 \pm 0.04 \mathrm{bB}$ & $1.45 \pm 0.10 \mathrm{bB}$ \\
\hline 12th Sep. & $1.79 \pm 0.21 \mathrm{aA}$ & $1.83 \pm 0.39 \mathrm{aB}$ & $1.88 \pm 0.34 \mathrm{aA}$ & $1.50 \pm 0.05 \mathrm{cCD}$ & $1.42 \pm 0.04 \mathrm{aB}$ & $1.45 \pm 0.12 \mathrm{bB}$ \\
\hline 24th Sep. & $1.67 \pm 0.20 \mathrm{aA}$ & $1.71 \pm 0.26 \mathrm{aA}$ & $1.82 \pm 0.50 \mathrm{bA}$ & $1.52 \pm 0.04 \mathrm{bD}$ & $1.42 \pm 0.07 \mathrm{aB}$ & $1.49 \pm 0.13 b c$ \\
\hline 10th Oct. & $2.75 \pm 0.70 \mathrm{bC}$ & $2.15 \pm 0.28 \mathrm{aC}$ & $2.51 \pm 0.42 \mathrm{bB}$ & $1.37 \pm 0.07 \mathrm{aA}$ & $1.37 \pm 0.02 \mathrm{aA}$ & $1.38 \pm 0.08 \mathrm{aA}$ \\
\hline 23rd Oct. & $2.52 \pm 0.20 \mathrm{bB}$ & $2.19 \pm 0.33 \mathrm{aC}$ & $2.56 \pm 0.17 \mathrm{bB}$ & $1.40 \pm 0.02 \mathrm{cAB}$ & $1.36 \pm 0.03 \mathrm{aA}$ & $1.38 \pm 0.07 \mathrm{bA}$ \\
\hline 6th Nov. & $2.57 \pm 0.12 \mathrm{bBC}$ & $2.40 \pm 0.29 \mathrm{aD}$ & $2.78 \pm 0.34 \mathrm{cC}$ & $1.41 \pm 0.01 \mathrm{bB}$ & $1.37 \pm 0.03 \mathrm{aA}$ & $1.37 \pm 0.06 \mathrm{aA}$ \\
\hline
\end{tabular}

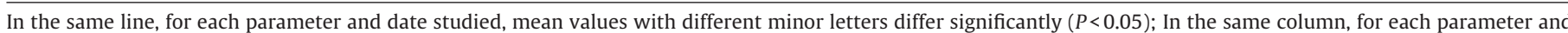
cultivar studied, mean values with different capital letters differ significantly $(P<0.05)$.

Table 4

Fatty acids profile of olives from cvs. Cobrançosa, Madural and Verdeal Transmontana at different maturation indices (mean values; $n=3$ ).

\begin{tabular}{|c|c|c|c|c|c|c|c|c|c|c|c|c|}
\hline & \multicolumn{4}{|c|}{ Cobrançosa } & \multicolumn{4}{|c|}{ Madural } & \multicolumn{4}{|c|}{ Verdeal Transmontana } \\
\hline & MI 0 & MI 1 & MI 2 & MI 3 & MI 0 & MI 1 & MI 2 & MI 3 & MI 0 & MI 1 & MI 2 & MI 3 \\
\hline $\mathrm{C}_{14: 0}$ & 0.01 & 0.01 & 0.01 & 0.01 & 0.01 & 0.01 & 0.01 & 0.01 & 0.01 & 0.01 & 0.01 & 0.01 \\
\hline$C_{16: 0}$ & 11.6 & 11.8 & 11.8 & 11.7 & 11.7 & 12.0 & 12.1 & 12.2 & 11.6 & 11.8 & 10.9 & 10.9 \\
\hline $\mathrm{C}_{16: 1}$ & 0.67 & 0.75 & 0.75 & 0.77 & 0.54 & 0.59 & 0.53 & 0.66 & 0.71 & 0.78 & 0.67 & 0.60 \\
\hline $\mathrm{C}_{17: 0}$ & 0.20 & 0.18 & 0.16 & 0.17 & 0.11 & 0.11 & 0.05 & 0.10 & 0.19 & 0.17 & 0.21 & 0.22 \\
\hline $\mathrm{C}_{17: 1}$ & 0.26 & 0.26 & 0.25 & 0.24 & 0.15 & 0.14 & 0.07 & 0.13 & 0.29 & 0.28 & 0.31 & 0.32 \\
\hline $\mathrm{C}_{18: 0}$ & 4.52 & 4.29 & 4.54 & 4.50 & 3.47 & 3.50 & 2.65 & 3.34 & 3.54 & 3.16 & 3.43 & 3.36 \\
\hline $\mathrm{C}_{18: 1}$ & 75.0 & 74.8 & 74.2 & 73.7 & 73.5 & 72.0 & 70.3 & 70.2 & 78.0 & 78.7 & 79.0 & 80.4 \\
\hline $\mathrm{C}_{18: 2}$ & 5.57 & 5.86 & 6.36 & 7.04 & 8.20 & 9.70 & 12.39 & 11.53 & 3.25 & 3.13 & 3.50 & 2.34 \\
\hline $\mathrm{C}_{18: 3}$ & 1.01 & 0.86 & 0.87 & 0.84 & 1.18 & 0.98 & 1.00 & 0.92 & 1.02 & 0.84 & 0.81 & 0.64 \\
\hline$C_{20: 0}$ & 0.58 & 0.51 & 0.51 & 0.51 & 0.46 & 0.43 & 0.36 & 0.38 & 0.60 & 0.51 & 0.52 & 0.53 \\
\hline$C_{20: 1}$ & 0.26 & 0.23 & 0.23 & 0.23 & 0.30 & 0.26 & 0.29 & 0.26 & 0.34 & 0.31 & 0.30 & 0.29 \\
\hline $\mathrm{C}_{22: 0}$ & 0.15 & 0.12 & 0.13 & 0.13 & 0.12 & 0.11 & 0.10 & 0.10 & 0.18 & 0.14 & 0.16 & 0.17 \\
\hline$C_{24: 0}$ & 0.07 & 0.06 & 0.06 & 0.05 & 0.07 & 0.05 & 0.04 & 0.04 & 0.11 & 0.08 & 0.07 & 0.07 \\
\hline SFA & 17.1 & 17.0 & 17.2 & 17.1 & 16.0 & 16.2 & 15.3 & 16.2 & 16.2 & 15.9 & 15.3 & 15.2 \\
\hline MUFA & 76.2 & 76.1 & 75.4 & 74.9 & 74.5 & 73.0 & 71.2 & 71.2 & 79.3 & 80.0 & 80.3 & 81.6 \\
\hline PUFA & 6.58 & 6.72 & 7.23 & 7.88 & 9.38 & 10.7 & 13.4 & 12.4 & 4.27 & 3.97 & 4.30 & 2.97 \\
\hline Trans isomers & 0.18 & 0.17 & 0.17 & 0.15 & 0.18 & 0.16 & 0.15 & 0.15 & 0.18 & 0.13 & 0.15 & 0.14 \\
\hline
\end{tabular}




\section{Conclusions}

The results obtained in the present work allowed to conclude that both physical and chemical parameters may be taken in consideration by olive fly for oviposition purposes. We concluded that the maturation process, which influences olives color and biometrical data, may contribute for oviposition preference as well. Olive leaves color is characteristic in each olive cultivar, with higher lightness being exhaled by the most susceptible olive cultivar, Verdeal Transmontana. Fatty acids profile is also characteristic in each cultivar and it could be an internal factor in olives for olive fly oviposition. The results obtained have also practical application in harvest and in the cultivation of new olive groves. An early harvest is encouraged to prevent higher losses due to the attack of olive fly. In the plantation of new olive orchards the right choice of olive cultivars is very important to point out to high quality olive products.

\section{Acknowledgements}

The authors are grateful to the Portuguese Foundation of Science and Technology for financial support through the project EXCL/AGR-PRO/0591/2012 "Olive crop protection in sustainable production under global climatic changes: linking ecological infrastructures to ecosystem functions" and Pest-C/EQB/LA0006/2013. Ricardo Malheiro thanks FCT, POPH-QREN and FSE for PhD grant (SFRH/BD/74675/2010). This manuscript is part of Ricardo Malheiro PhD Thesis.

\section{References}

AOAC, 2000. In: Horwitz, W. (Ed.), Official Methods of Analysis of AOAC International, II, 17th ed. AOAC, Arlington, VA, pp. 1-3.

Arrese, E.L., Soulages, J.L., 2010. Insect fat body: energy, metabolism, and regulation. Annu. Rev. Entomol. 55, 207-225.

Burrack, H.J., Bingham, R., Price, R., Connell, J.H., Phillips, P.A., Wunderlich, L., Vossen, P.M., O'Connell, N.V., Fergunson, L., Zalom, F.G., 2011. Understanding the seasonal and reproductive biology of olive fruit fly is critical to its management. Calif. Agric. 65, 14-20.

Commission Regulation, 1991. (EEC) n 2568/91: on the characteristics of olive oil and olive-pomace oil and on the relevant methods of analysis. Off. J. Eur. Union L248, 1-82.
Daane, K.M., Jonhson, M.W., 2010. Olive fruit fly: managing an ancient pest in modern times. Annu. Rev. Entomol. 55, 151-169.

FAOSTAT, 2015. Food and Agriculture Organization, FAOSTAT Database. Available at: http://faostat3fao.org/browse/O/OC/E. (accessed 12.03.15.).

Gómez-Caravaca, A.M., Cerretani, L., Bendini, A., Segura-Carretero, A. Fernández-Gutiérrez, A., Del Carlo, M., Compagnone, D., Cichelli, A., 2008 Effects of fly attack (Bactrocera oleae) on the phenolic profile and selected chemical parameters of olive oil. J. Agric. Food Chem. 56, 4577-4583.

Gonçalves, M.F., Malheiro, R., Casal, S., Torres, L., Pereira, J.A., 2012. Influence of fruit traits on oviposition preference of the olive fly, Bactrocera oleae (Rossi) (Diptera: Tephritidae), on three Portuguese olive varieties (Cobrancosa, Madural and Verdeal Transmontana). Sci. Hort. 145, 127-135.

Guinda, A., Rada, M., Delgado, T., Gutiérrez-Adánez, P., Castellano, J.M., 2010. Pentacyclic triterpenoids from olive fruit and leaf. J. Agric. Food Chem. 58, 9685-9691.

Hermoso, M., Uceda, M., Frias, L., Beltrán, G., 2001. Maduración. In: Barranco, D., Fernández-Escobar, R., Rallo, L. (Eds.), El cultivo del olivo. Ediciones Mundi-Prensa, Madrid, pp. 153-170.

International Olive Council (IOC), 2014. World Olive Oil Figures-Production. Available at: http://www.internationaloliveoil.org/estaticos/view/131-worldolive-oil-figures. (accessed 12.03.15.).

Katsoyannos, B.I., Patsouras, G., Vrekoussi, M., 1985. Effect of color hue and brightness of artificial oviposition substrates on the selection of oviposition by Dacus oleae. Entomol. Exp. Appl. 38, 205-214.

Kombargi, W.S., Michelakis, S.E., Petrakis, C.A., 1998. Effect of olive surface waxes on oviposition by Bactrocera oleae (Diptera: Tephritidae). J. Econ. Entomol. 91, 993-998

Malheiro, R., Casal, S., Cunha, S.C., Baptista, P., Pereira, J.A., 2015. Olive volatiles from Portuguese cultivars Cobrancosa, Madural and Verdeal Transmontana: role in oviposition preference of Bactrocera oleae (Rossi) (Diptera: Tephritidae). Plos One 10, 1-15.

Malheiro, R., Casal, S., Sousa, A., Pinho, P.G., Peres, A.M., Dias, L.G., Bento, A., Pereira, J.A., 2012. Effect of cultivar on sensory characteristics, chemical composition, and nutritional value of stoned green table olives. Food Bioprocess. Technol. 5 1733-1742

Neuenschwander, P., Michelakis, S., Holloway, P., Berchtold, W., 1985. Factors affecting the susceptibility of fruits of different olive varieties to attack of Dacus oleae (Gmel.) (Dipt., Tephritidae). Z. Ang. Ent. 100, 174-188.

Peragón, J., 2013. Time course of pentacyclic triterpenoids from fruits and leaves of olive tree (Olea europaea L.) cv. Picual and cv. Cornezuelo during ripening. J. Agric. Food Chem. 61, 6671-6678

Pereira, J.A., Alves, M.R., Casal, S., Oliveira, M.B.P.P., 2004. Effect of olive fruit fly infestation on the quality of olive oil from cultivars Cobrancosa, Madural, and Verdeal Transmontana. Ital. J. Food Sci. 16, 355-365.

Rizzo, R., Caleca, V., Lombardo, A., 2012. Relation of fruit color, elongation, hardness, and volumen to the infestation of olive cultivars by the olive fruit fly, Bactrocera oleae. Entomol. Exp. Appl. 145, 15-22.

Zhang, G.-N., Hu, F., Dou, W., Wang, J.-J., 2012. Morphology and distribution of sensilla on tarsi and ovipositors of six fruit flies (Diptera: Tephritidae). Ann. Entomol. Soc. Am. 105, 319-327. 